\title{
Possibility of utilization of two Aegilops sp. to enhance the nutritive value of triticale
}

\author{
D. Boros ${ }^{1,3}$, M. Ploch ${ }^{1}$ and D. Gruszecka ${ }^{2}$ \\ ${ }^{1}$ Institute of Plant Breeding and Acclimatization - National Research Institute, \\ Laboratory of Quality Evaluation of Plant Materials \\ 05-870 Radzików, Poland \\ ${ }^{2}$ University of Life Sciences, Institute of Plant Genetic, Breeding and Biotechnology \\ Akademicka 13, 20-950, Lublin, Poland
}

(Received 29 October 2009; revised version 23 September 2010; accepted 26 November 2010)

\begin{abstract}
Study was undertaken to determine the possibility of improving the nutritive value of triticale by crossing it with two species of Aegilops. Materials for this study comprised of 5 triticale recombinants with Aegilops crassa Boiss 4x and Aegilops juvenalis (Thell) and 4 parental triticale forms. Parental species of Aegilops were not analysed because of difficulties in obtaining the needed quantity and quality of the grains. As compared to parental triticale forms the recombinants of triticale with Aegilops sp. characterized with a greater thousand kernel weight and volume weight, higher content of protein and dietary fibre, especially of its soluble non-starch polysaccharides fraction. Aegilops sp. had not a negative effect on digestibility of protein. The higher content of protein in triticale recombinants resulted however, in poorer values of protein quality indicators, such as lysine content, chemical score, essential amino acid index, biological value and net protein utilization. The other qualitative traits in hybrids did not differ from that received for parental forms. This preliminary study has shown that Aegilops crassa might be utilized for the improvement of triticale grain designated rather for food production, while Aegilops juvenalis for feeding purposes. Selection of appropriate triticale forms it seems also very important in this respect.
\end{abstract}

KEY WORDS: triticale, Aegilops sp., chemical composition, dietary fibre, nutritive value

\footnotetext{
* Presented in part at the Scientific Session of the Committee of Animal Sciences, Polish Academy of Sciences, 2007

${ }^{3}$ Corresponding author: e-mail: d.boros@ihar.edu.pl
} 


\section{INTRODUCTION}

Qualitative cereals are becoming more and more important as well as desired products for intensively developing various branches of cereal industry. These facts open new challenges for breeders to create cultivars that will satisfy specific requirements for different end-uses of cereals. In nutrition, cereals besides being a main source of energy and a substantial source of protein, constitute also the important source of bioactive components such as dietary fibre, phenolics, sterols, tocols, vitamins, minerals, all having positive effects on human health (Liu, 2007; Topping, 2007). Many breeding programmes presently conducted world-wide have been carried out to select or develop cereals with changes in the content of arabinoxylans, $\beta$-glucans, i.e. the main constituents of dietary fibre, or amylose as the precursor of resistant starch formation during heat processing (Monari et al., 2005; Saulnier etal., 2007). In contrary to human nutrition, dietary fibre is considered as anti-nutrient for monogastric animals, especially their soluble components due to high viscous properties when in aqueous solution (Choct and Annison, 1990). It has been well known that high viscosity of ileum digesta is associated with low digestibility and low availability of all nutrients and in consequence with poor feed utilization and decreased body weight (Bedford et al., 1991; Langhout et al., 2000). Triticale up to now is almost exclusively utilized as feed for animals but it has also a great potential to be exploited as an alternative cereal in human nutrition (Boros, 2006; Marciniak et al., 2006). Further improvement its nutritive value is thus highly important.

Various Aegilops species, such as Ae. ventricosa, Ae. speltoides L. Ae. squarrosa L., Ae. umbellulata Zhuk., Ae. comosa Sibth. et Sm. and Ae. markgrafii L. are widely exploiting as new genetic donors of agronomically important traits. Using these wild species, throughout distant hybridization many wheat breeding lines have been developed with the improved resistance to powdery mildew and various types of rust diseases (Delibes et al., 1987; Kerber and Dyck, 1990; Strzembicka and Gruszecka, 1997). Quality characters are also targeted, such as high molecular weight glutenins present in Ae. umbellulata or Ae. tauschii, utilized for improving bread-making quality of wheat (Liu et al., 2003). The impact of Aegilops on the content of dietary fibre and its major constituents has not been studied yet in their recombinants with triticale. No information is also available on the nutritive usability of such hybrids.

Aim of the study was to determine the possibility of using two Aegilops species, Ae. crassa and Ae. juvenalis, to enhance the nutritive value of triticale. 


\section{MATERIAL AND METHODS}

Material comprised of three recombinants of triticale with Aegilops crassa Boiss 4x, two with Aegilops juvenalis (Thell.) Eig. and of four different triticale parental forms produced at the same environmental conditions. All hybrid forms of triticale were genetically stabilized at the hexaploid level. Parental species of Aegilops were not included in the study due to difficulties in obtaining the needed quantity and quality of the grains.

The following physicochemical parameters were determined: thousand kernel mass (TKM), hectolitre mass (HM), content of protein, ash and lipids that were analysed according to the AACC methods (2000). N-free extractives (NFE) was calculated with slighty modified methods as by difference of protein, ash, lipids and Klason lignin (Theander et al., 1995) analyses. The amino acids content was determined using ion-exchange chromatography on an AAA-400 amino acid analyzer (INGOS, the Czech Republic) in accordance to the procedure of Moore and Stein (1963), in which proteins were hydrolysed with $6 \mathrm{~N} \mathrm{HCl}$ for $24 \mathrm{~h}$ at $100^{\circ} \mathrm{C}$, after earlier oxidation of cystine and methionine with performic acid (Mason et al., 1980). Basing on amino acid content chemical score (CS) and essential amino acid index (EAA) were calculated as the protein quality indicators.

Grain samples were also analysed for the content of total dietary fibre (TDF) by the Uppsala method (AACC 32-25) as a sum of non-starch polysaccharides (NSP) and Klason lignin. The monosaccharide composition of the soluble and insoluble NSP polymers was analysed as alditol acetates by gas chromatography, as described by Englyst and Cummings (1984). A Hewlett-Packard 5890, Series II gas chromatograph was used, equipped with a flame ionization detector and Rtx 225 capillary column (30 m length and $0.53 \mathrm{~mm}$ id; cat \#14049 from Restek Corporation, 110 Benner Circle, Bellefonte, USA). Temperature of the detector was $250^{\circ} \mathrm{C}$ and that of the injector $220^{\circ} \mathrm{C}$. The column oven programme started at $190^{\circ} \mathrm{C}$ increasing by $5^{\circ} \mathrm{C} / \mathrm{min}$ up to $215^{\circ} \mathrm{C}$ and holding this temperature for 5 min. Helium was used as a carrier gas. Total and insoluble fractions of NSP were calculated as the sum of appropriate monosaccharide residues and presented as anhydrous polymers. Soluble fraction of NSP is calculated from the difference between total and insoluble content of NSP. Viscosity was measured in water extracts prepared from wholemeal samples shaken with distilled water at a ratio $1: 10 \mathrm{w} / \mathrm{v}$ on Brookfield Cone/Plate Digital Viscometer, with a $0.8^{\circ}$ cone spindle and shear rate of $225 \mathrm{sec}$ applied at $30^{\circ} \mathrm{C}$ (Boros et al. , 1993). All analyses were performed in duplicate and expressed on dry matter basis.

The balance trial was performed on rats using the general procedure of Eggum (1973). Ten experimental groups, each comprised of five male Wistar rats with an 
initial weight of $72.5 \pm 3.0 \mathrm{~g}$ were used to evaluate digestibility of dry matter (DMD) and protein (TPD), its biological value (BV) as well as net utilization (NPU). The rats were kept individually in metabolic cages and fed a fixed amount of diet, equals $10 \mathrm{~g}$ of $\mathrm{DM} /$ day, with a free access to water. A preliminary period lasted 4 days and a balance period 5 days. Body weight and feed intake were recorded at the end of the each period. During the balance period urine and faeces were collected separately. The diets contained equal amount of tested grains $(80 \%)$ and were supplemented with vitamin (1\%) and mineral (3.5\%) mixtures, soyabean oil $(5 \%)$ and wheat starch $(10.5 \%)$. Casein diet containing $9.4 \%$ of protein was used as a reference diet. The experiment was conducted in compliance with European Union regulations concerning the protection of experimental animals and the study protocol was approved by the local ethics committee.

One-way analysis of variance was carried out with the GLM Procedure of SAS ${ }^{\circledR}$ not? and means were compared using Duncan's multiple range test. Pearson's correlation coefficients were calculated for all qualitative indices.

\section{RESULTS AND DISCUSSION}

All kernels of triticale hybrid lines with Aegilops sp. were well developed and plumped as compared to kernels of their parental forms (Table 1). The average TKM of hybrids was $50.7 \mathrm{~g}$, exceeding their parental forms by $19 \%$, except for the progeny of cultivar Presto, with no changes observed ( 46.0 vs $46.3 \mathrm{~g}$ ). The differences between hybrids and triticale parental forms in HM were not so clearly visible, on average only $4 \%$, but there were found high positive influence of $A e$. juvenalis on their offspring (higher by $11 \%$ ), independent on the parental form of triticale used. Recombinants of triticale and Aegilops sp. were also superior to the parental forms in the respect of protein content. An average amount of protein was $125 \mathrm{~g} / \mathrm{kg}$ in the parental forms and $137 \mathrm{~g} / \mathrm{kg}$ in the hybrid lines. Hybrids of Ae. crassa with two triticale forms, cultivar Presto and primary line of wheat Panda and rye Dańkowskie Złote showed protein content higher even by 14 and 17\%, respectively. Values of the remaining basic grain components, i.e. ash, lipids and nitrogen free extractives in hybrids of triticale with Aegilops sp. were similar to the parental forms with the exception of lipid content in the hybrid of Ae. crassa and line $[($ Lanca $\times$ L506/79) $\times$ CZR 142/79] exceeding by $22 \%$ parental forms.

Hybrids of triticale and Aegilops sp. characterized also, on average, by the increased content of total DF and its components, especially soluble fraction of NSP, mainly arabinoxylans (by 8,32 and $52 \%$, respectively) as compared to triticale parental forms (Table 2). Higher contents of soluble fraction of NSP in 


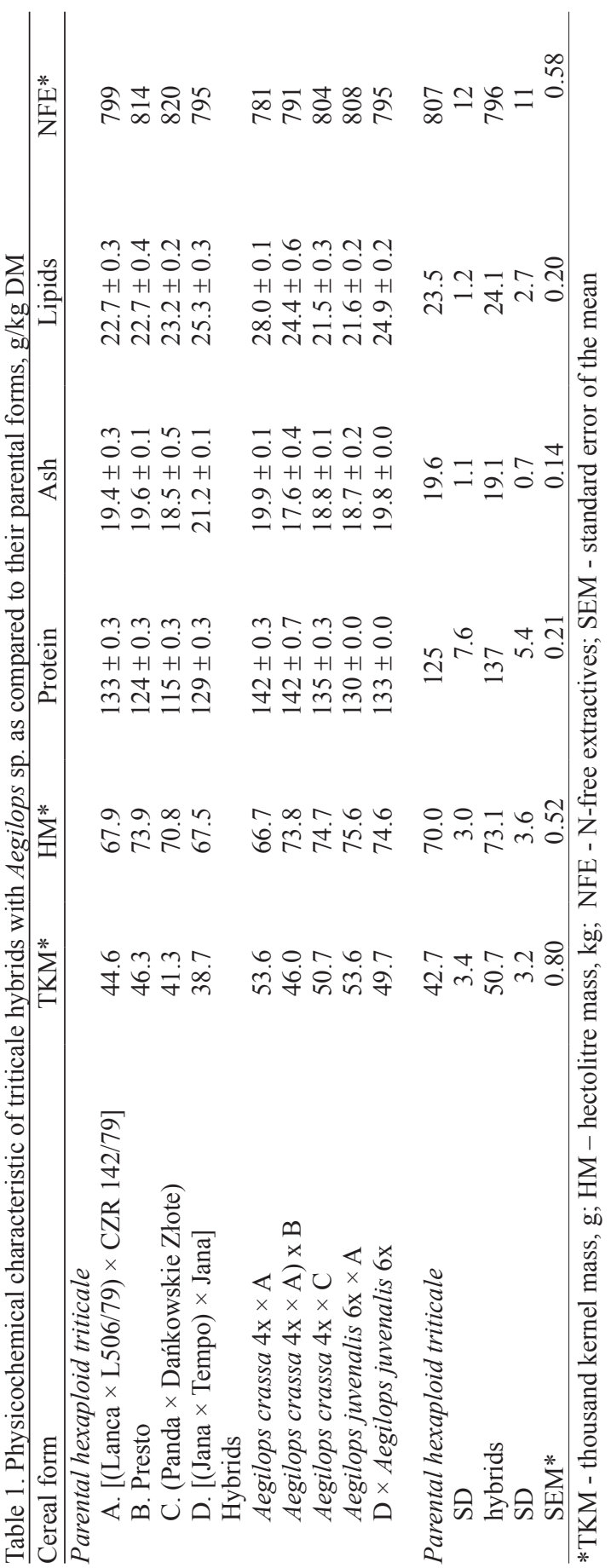


hybrids, arabinoxylans in particular, were not accompanied by the proportional increase in water extract viscosity (WEV) values. This findings is in contrast with the results of earlier studies, that showed a high relationship between the level of soluble arabinoxylans and the viscosity of water extract in such cereals as: wheat, triticale and rye, in which these polysaccharides constitute the major soluble component of DF (Boros et al., 1993). Viscous properties of soluble arabinoxylans depend on many factors, among them, concentration in the grain, degree of polymerization, molecular weight, association with other grain components, that acting synergistically (Bengtsson et al., 1992; Izydorczyk and Biliaderis, 1995). Lack of significant relationship between viscosity and content of soluble fractions of NSP might indicate the involvement of other factors, possibly preharvest sprouting in some samples analysed, resulting in hydrolysis of arabinoxylans and changing their structure to less viscous oligosaccharides polymers. It might also indicate differences in the structure and properties of dietary fibre and its constituents in Aegilops species and triticale forms used. Different structure and properties of dietary fibre constituents could be envisaged by contrasting impact of Ae. crassa and Ae. juvenalis on their recombinants with the same triticale line [(Lanca $\times$ L506/79) $\times$ CZR 142/79]. Total contents of DF and NSP and above all its soluble fractions were considerably increased in the recombinant with Ae. crassa (by 24, 27 and $81 \%$, respectively). In this recombinant threefold increase in content of soluble arabinoxylans was even observed, while viscosity of water extract of their grain was only slightly higher (by 6\%). Recombinant with Ae. juvenalis showed similar to triticale line level of TDF $(110 \mathrm{~g} / \mathrm{kg})$, slightly greater amount of total NSP ( $89 \mathrm{vs} 84 \mathrm{~g} / \mathrm{kg}$ ) and its soluble fraction (15 vs $13 \mathrm{~g} / \mathrm{kg}$ ), with decreased (by $5 \%)$ WEV value.

As expected, the quality of protein in the hybrids due to increased content of protein was reduced (Table 3). It was illustrated by decreased content of lysine and other essential amino acids as well as EAA index. In all grains first limiting amino acid was lysine with CS from 37 to 45, while second limiting amino acid was isoleucine in 7 samples with CS in range from 56.8 to 62.4 or threonine in two samples with CS equal 60.8. There was not found any impact of Aegilops sp. on digestibility of protein in the grain of their offspring (on average 90.3 vs 89.7), except for the negative effect $(\mathrm{P}<0.05)$ of genes recombination of Ae. crassa with cultivar Presto (92.0 vs 89.1). However, the higher content of protein in recombinants as compared to triticale parental forms resulted in poorer values of protein quality indices, such as lysine content, CS, BV and NPU (Tables 3 and 4). Both, lysine content and EAA index were negatively correlated $(\mathrm{P}<0.01, \mathrm{r}=-0.86$ and -0.72$)$ with TKM, confirming that the smaller grains have higher share of aleurone layer in total kernel mass. In cereals with starchy endosperm, the aleurone is proteinaceous part of the kernel reach in the essential 


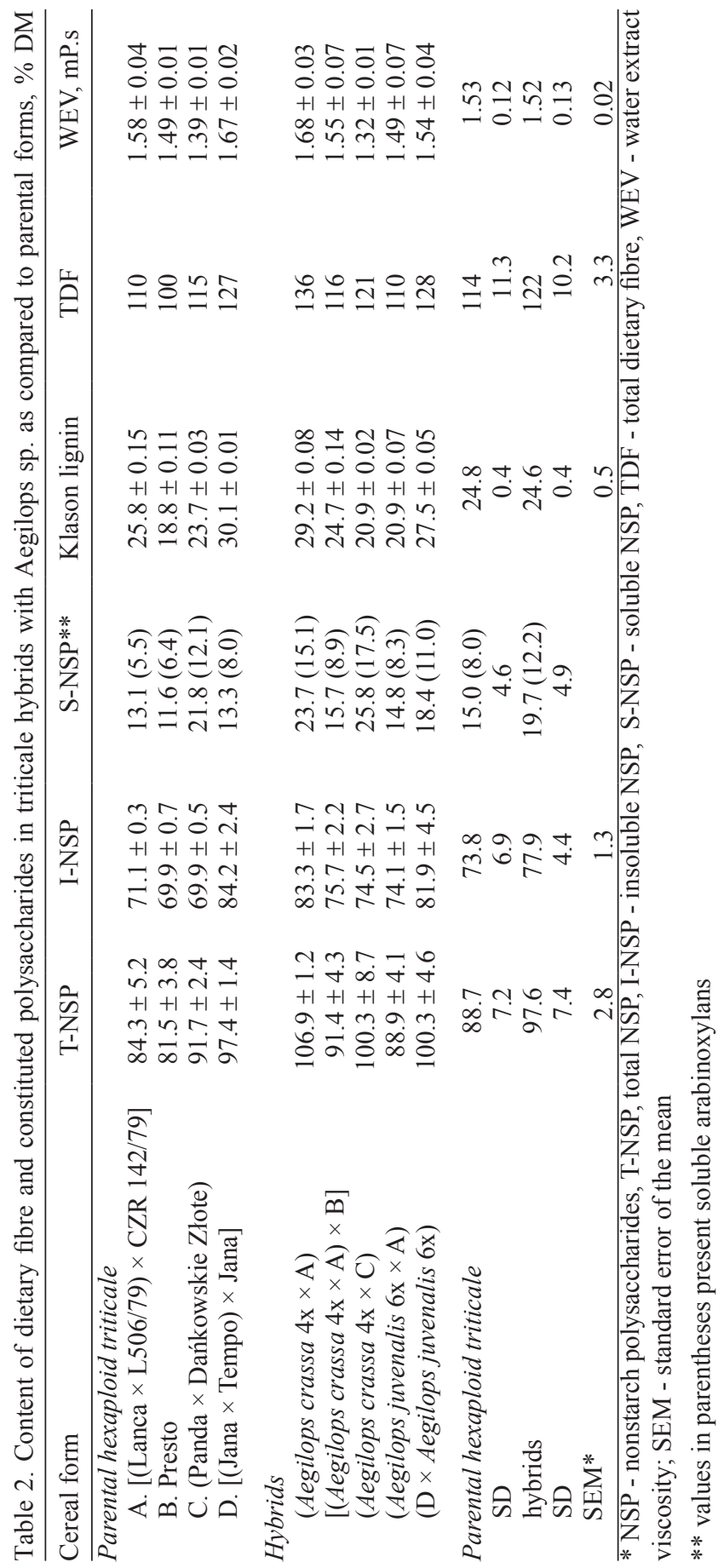


Table 3. Content of limiting essential amino acids and qualitative protein indices of triticale hybrids with Aegilops sp. as compared to their parental forms,g/16 g N

\begin{tabular}{|c|c|c|c|c|c|c|}
\hline Cereal form & Lys* & Thre* & $\begin{array}{l}\text { Met }+ \\
\text { cys* }\end{array}$ & $\begin{array}{c}\text { Sum } \\
\text { of EAA* }\end{array}$ & $\mathrm{CS}^{*}$ & $\begin{array}{l}\text { Index } \\
\text { EAA* }\end{array}$ \\
\hline \multicolumn{7}{|l|}{ Parental hexaploid triticale } \\
\hline A. $[($ Lanca $\times$ L506/79) $\times$ CZR $142 / 79]$ & 2.88 & 3.09 & 3.94 & 32.6 & 41.2 & 70.4 \\
\hline B. Presto & 2.95 & 3.00 & 4.09 & 31.3 & 42.1 & 68.1 \\
\hline C. $($ Panda $\times$ Dańkowskie Złote $)$ & 3.10 & 3.12 & 4.27 & 32.6 & 44.2 & 71.6 \\
\hline D. $[($ Jana $\times$ Tempo $) \times$ Jana $]$ & 3.16 & 2.96 & 4.17 & 31.6 & 45.1 & 69.1 \\
\hline \multicolumn{7}{|l|}{ Hybrids } \\
\hline Aegilops crassa $4 \mathrm{x} \times \mathrm{A}$ & 2.83 & 2.86 & 4.00 & 31.1 & 40.4 & 67.2 \\
\hline Aegilops crassa $4 \mathrm{x} \times \mathrm{A}) \times \mathrm{B}$ & 2.82 & 2.86 & 3.46 & 30.6 & 40.3 & 65.6 \\
\hline Aegilops crassa $4 \mathrm{x} \times \mathrm{C}$ & 2.60 & 2.92 & 3.65 & 29.8 & 37.2 & 64.3 \\
\hline Aegilops juvenalis $6 \mathrm{x} \times \mathrm{A}$ & 2.62 & 2.95 & 4.05 & 32.1 & 37.4 & 65.3 \\
\hline $\mathrm{D} \times$ Aegilops juvenalis $6 \mathrm{x}$ & 2.66 & 2.75 & 4.17 & 31.6 & 38.0 & 64.9 \\
\hline Parental hexaploid triticale & 3.0 & 3.0 & 4.1 & 32.0 & 43.2 & 69.8 \\
\hline SD & 0.1 & 0.1 & 0.1 & 0.7 & 1.8 & 1.5 \\
\hline hybrids & 2.7 & 2.9 & 3.9 & 31.0 & 38.7 & 65.5 \\
\hline SD & 0.1 & 0.1 & 0.3 & 0.9 & 1.6 & 1.1 \\
\hline
\end{tabular}

* Lys - lysine, thre - threonine, met+cys - methionine and cystein, EAA - essential amino acids, CS - chemical score

Table 4. Digestibility and utilization of protein and dry matter in triticale hybrids with Aegilops sp. as compared to their parental forms

\begin{tabular}{|c|c|c|c|c|}
\hline Cereal form & TPD* & $\mathrm{BV}^{*}$ & NPU* & DMD* \\
\hline$\overline{\text { Casein - reference diet }}$ & $97.0^{a}$ & $98.1^{a}$ & $95.2^{a}$ & $96.6^{a}$ \\
\hline \multicolumn{5}{|l|}{ Parental hexaploid triticale } \\
\hline A $[($ Lanca $\times$ L506/79) $\times$ CZR 142/79] & $90.6^{\mathrm{bc}}$ & $70.6^{\mathrm{c}}$ & $63.9^{\mathrm{c}}$ & $89.8^{\mathrm{cd}}$ \\
\hline B Presto & $92.0^{\mathrm{b}}$ & $74.9^{\mathrm{b}}$ & $68.9^{\mathrm{b}}$ & $90.7^{\mathrm{b}}$ \\
\hline C $\quad($ Panda $\times$ Dańkowskie Zł. $)$ & $88.9^{c}$ & $66.2^{\mathrm{d}}$ & $58.9^{\mathrm{de}}$ & $89.6^{\mathrm{cd}}$ \\
\hline $\mathrm{D}[($ Jana $\times$ Tempo $) \times$ Jana $]$ & $89.8^{\mathrm{bc}}$ & $73.5^{\mathrm{b}}$ & $66.0^{\mathrm{bc}}$ & $89.0^{\text {de }}$ \\
\hline \multicolumn{5}{|l|}{ Hybrids } \\
\hline Aegilops crassa $4 \mathrm{x} \times \mathrm{A}$ & $89.3^{c}$ & $65.7^{\mathrm{d}}$ & $58.7^{\mathrm{de}}$ & $88.5^{\mathrm{e}}$ \\
\hline (Aegilops crassa $4 \mathrm{x} \times \mathrm{A}) \times \mathrm{B}$ & $89.1^{\mathrm{c}}$ & $65.4^{\mathrm{de}}$ & $58.3^{\mathrm{de}}$ & $89.1^{\text {de }}$ \\
\hline Aegilops crassa $4 \mathrm{x} \times \mathrm{C}$ & $89.7^{\mathrm{c}}$ & $64.1^{\text {de }}$ & $57.5^{\mathrm{de}}$ & $90.3^{\mathrm{bc}}$ \\
\hline Aegilops juvenalis $6 \mathrm{x} \times \mathrm{A}$ & $90.3^{\mathrm{bc}}$ & $66.7^{\mathrm{d}}$ & $60.3^{\mathrm{d}}$ & $90.4^{\mathrm{bc}}$ \\
\hline $\mathrm{D} \times$ Aegilops juvenalis $6 \mathrm{x}$ & $90.0^{\mathrm{bc}}$ & $62.7^{\mathrm{e}}$ & $56.5^{\mathrm{e}}$ & $89.0^{\text {de }}$ \\
\hline Pooled SEM & 0.79 & 1.01 & 1.22 & 0.32 \\
\hline
\end{tabular}

*TPD - true protein digestibility, BV -biological value, NPU - net protein utilization, DMD - dry matter digestibility

amino acids, therefore their share in the kernel, significantly influences quality of the whole grain proteins. Since aleurone layer is built of thick-walled cells, tightly packed, liberation of amino acids due to enzymatic hydrolyses in the digestive tract of rats was hampered, resulting in decreased protein utilization. 
At the time when triticale was introduced into field production it has been acknowledged to be of high nutritive potential for human (Hulse and Laing, 1974), although, poor gluten quality deprived it from being utilized for breadmaking. The poor gluten quality is the reason that until now triticale has been considered almost exclusively as a cereal component in animal feeds. The feeding value of modern triticale cultivars for monogastric animals is high, equal or sometimes even better than wheat cultivars (Myer, 1998; Boros, 2002). In our earlier study, Polish triticale cultivars of superior nutritive value were characterized by high TKM, low content of soluble arabinoxylans and low viscosity of grain water extract (Boros, 2002). To maintain or further improve the high quality of triticale for feeding purposes the above three criteria should be taken into account in breeding programmes. Another approaches that have already been undertaken to further improve feeding value of triticale is transfer of genes bearing valuable traits from other wild grasses and supplementation of feed mixtures with appropriate enzymes (Fabijańska et al., 2007).

\section{CONCLUSIONS}

Recombination of triticale and Aegilops sp. genes increased the range of variability in the content of protein and dietary fibre in their progenies. The preliminary study indicates that Aegilops crassa might be used for quality improvement of triticale and possibly other cereals designated for human consumption, while Aegilops juvenalis is better when enhancement of feeding value is expected. Due to increased protein content recombinants of triticale and Aegilops sp. characterized with the poorer chemical quality indicators of protein, its biological value and net utilization.

\section{REFERENCES}

AACC, 2000. American Association of Cereal Chemists Inc. St. Paul, MN

Bedford M.R., Classen H.L., 1992. Reduction of intestinal viscosity through manipulation of dietary rye and pentosanase concentration is effected through changes in the carbohydrate composition of the intestinal aqueous phase and results in improved growth rate and food conversion efficiency of broiler chicks. J. Nutr. 122, 560-569

Bengtsson S., Andersson R., Westerlund E., Åman P., 1992. Content, structure and viscosity of soluble arabinoxylans in rye grain from several countries. J. Sci. Food Agr. 58, 331-337

Boros D., 2002. Physico-chemical quality indicators suitable in selection of triticale for high nutritive value. In: Proceedings of International Triticale Symposium. Radzików (Poland), Vol. I, 239-244

Boros D., 2006. Triticale of high end-use quality enhances opportunities to increase its value in world cereals market. In: Proceedings of the 6th International Triticale Symposium. Stellenbosch (South Africa). (C) 2006 ITA \& SU-PBL - Faculty of AgriSciences, Stellenbosch, pp. 118-124 
Boros D., Marquardt R.R., Slominski B.A., Guenter W., 1993. Extract viscosity as an indirect assay for water-soluble pentosan content in rye. Cereal Chem. 70, 575-580

Choct M., Annison G., 1990. Anti-nutritive activity of wheat pentosans in broiler diets. Brit. Poultry Sci. $31,811-822$

Delibes A., Lopez-Braña I., Mena M., García-Olmedo F., 1987. Genetic transfer of resistance to powdery mildew and of an associated biochemical marker from Aegilops ventricosa to hexaploid wheat. Theor. Appl. Genet. 73, 605-608

Eggum B.O., 1973. A study of certain factors influencing protein utilization in rats and pigs. Beretn. Report, 406. National Institute of Animal Science. Copenhagen, pp. 173

Englyst H.N., Cummings J.H., 1984. Simplified method for the measurement of total non-starch polysaccharides by gas-liquid chromatography of constituent sugars as alditol acetates. Analyst 109, 937-942

Fabijanska M., Gruszecka D., Kosieradzka I., Mieczkowska A., Smulikowska S., 2007. Effects of feed enzymes on nutritive value of hybrid triticale x Agrotriticum kernels for broiler chickens. J. Anim. Feed Sci. 16, 225-231

Hulse J.H., Laing E.M., 1974. Nutritive Value of Triticale Protein. Publ. International Development Research Centre, Ottawa (Canada)

Izydorczyk M., Biliaderis C.G., 1995. Cereal arabinoxylans: advances in structure and physicochemical properties. Carbohyd. Polym. 28, 33-48

Kerber E.R., Dyck P.L., 1990. Transfer to hexaploid wheat of linked genes for adult-plant leaf rust and seedling stem rust resistance from an amphiploid of Aegilops speltoides x Triticum monococcum. Genome 33, 530-537

Langhout D.J., Schutte J.B., de Jong J., Sloetjes H., Verstegen M.W.A., Tamminga S., 2000. Effect of viscosity on digestion of nutrients in conventional and germ-free chicks. Brit. J. Nutr. 83, 533-540

Liu R.H., 2007. Whole grain phytochemicals and health. J. Cereal Sci. 46, 207-219

Liu Z., Yan Z., Wan Y., Liu K., Zheng Y., Wang D., 2003. Analysis of HMW glutenin subunits and their coding sequences in two diploid Aegilops species. Theor. Appl. Genet. 106, 1368-1378

Marchello J.A., Dryden F.D., Hale W.H., 1971. Bovine serum lipids. I. The influence of added animal fat on the ration. J. Anim. Sci. 32, 1008-1015

Marciniak A., Obuchowski W., Budzyńska K., Ziemska E., 2006. The usefulness of some Triticale varietes as a material of potential funcional properties. Cereal Milling Rev. 10, 16-18, 28

Mason V.C., Bech-Andersen S., Rudemo M., 1980. Hydrolysate preparation for amino acid determination in feed constituents. Z. Tierphysiol. Tierernähr. Futtermittelk. 43, 35-48

Monari A.M., Simeone M.C., Urbano M., Margiotta B., Lafiandra D., 2005. Molecular characterization of new waxy mutants identified in bread and durum wheat. Theor. Appl. Genet. $110,1481-1489$

Moore S., Stein W.M., 1963. Chromatographic determination of amino acid by use automatic recording equipment. In: P. Colowick, N.O. Caplan (Editors). Methods in Enzymology. Academic Press Inc. New York, Vol. VI, 819-831

Myer R.O., 1998. Evaluation of triticale in nursery diets for early weaned pigs. In: Proceedings of the $4^{\text {th }}$ International Triticale Symposium. Red Deer, Alberta (Canada), Vol. 1, 196-200

Saulnier L., Sado P-E., Branlard G., Charmet G., Guillon F., 2007. Wheat arabinoxylans: exploiting variation in amount and composition to develop enhanced varieties. J. Cereal Sci. 46, 261-281

Strzembicka A., Gruszecka D., 1997. Characteristics of X Triticosecale Wittmack with Aegilops sp. hybrids with respect to their reaction to leaf rust. J. Appl. Genet. 38, 129-134

Theander O., Åman P., Westerlund E., Andersson R., Pettersson D., 1995. Total dietary fiber determined as neutral sugar and uronic acid residues, and lignin (The Uppsala method): Collaborative study. J. Assn. Off. Anal. Chem. 78, 1030-1044

Topping D., 2007. Cereal complex carbohydrates and their contribution to human health. J. Cereal Sci. 46, 220-229 